\title{
Third Industry Supply Side Innovation of State Owned Enterprises Audit Efficiency Measurement Countermeasures
}

\author{
Jie $\mathrm{Xu}^{1, \mathrm{a}}{ }^{*}$ and Xing $\mathrm{Li}^{1, \mathrm{~b}}$ \\ ${ }^{1}$ Economics and Management College of Longdong University, Qingyang Gansu 745000 \\ a15213866789@139.com, ${ }^{\mathrm{b}}$ leebj@189.cn \\ * the corresponding author
}

Keyword: Audit issues ; State-owned enterprises ;Countermeasure analysis

\begin{abstract}
This study was based on China audit Yearbook data from 2008 to 2014, based on BCC model of data envelopment analysis and Malmquist index method to measure the audit efficiency of state-owned enterprises, study finds: The static efficiency measurement of state-owned enterprises shows that the comprehensive efficiency, pure technical efficiency and scale efficiency are not up to the standard efficiency value, and the overall audit efficiency is not ideal; The average value of regional audit static efficiency shows obvious regional characteristics, and the degree of difference is significant, the level of regional economic development will affect the realization of audit immune system function; The measurement results of state-owned enterprises' dynamic efficiency show that the audit efficiency of state-owned enterprises in China is declining, and the decline of scale efficiency is the main reason for the decline of technical efficiency, realize the balance of audit efficiency is the key to eliminate regional differences and analyze how to optimize the audit countermeasures of state-owned enterprises.
\end{abstract}

\section{Introduction}

General Office of the CPC Central Committee, General Office of the State Council explicitly put forward Framework opinions on several important issues of improving audit system in 2015: By 2020, the audit supervision mechanism that basically adapts to the modernization of the national governance system and governance capacity will be formed, it will give full play to the important role of audit in ensuring the implementation of national major decision-making, safeguard national economic security, promote deepening reform, promote the rule of law, and promote the construction of an honest and clean government. The improvement of audit efficiency is of great significance to improve the audit management system of independent exercise of audit supervision power and play the role of audit in the party and state supervision system. There is theoretical and practical value to study the audit efficiency of state-owned enterprises.

\section{Discussion on the Audit of State Owned Enterprises}

State owned assets are closely related to the interests of the people, it is an important part of the economic construction. Enterprises must ensure the stability of state-owned assets when they carry out the deepening reform of audit institutions. The domestic economy is now in the transition stage, all walks of life are under the background of deepening the reform in depth to carry out their own internal adjustment work in order to conform to the development of social and economic trends .With the continuous development of national economy, the importance of audit work of state-owned enterprises is gradually reflected. Under the overall deepening reform, the audit institutions of state-owned enterprises need to speed up the pace of reform and pay attention to the audit effect. The audit items of state-owned enterprises are various, the audit scope is extensive, and the audit process is complex. In order to further optimize the audit institutions, it will inevitably face many obstacles and difficulties. From the current market economy environment, there is intense competition among various industries, state-owned enterprises original audit model has been unable to adapt to the pace of development of the market environment, enterprises must carry out 
audit mode based on the current situation of market economy adjustment. Under the overall deepening reform, the reform of state-owned enterprises is becoming more and more difficult, which makes the adjustment of enterprise audit mode more difficult. The audit supervision of state-owned enterprises is analyzed. The current supervision power of economic audit is relatively dispersed, and the supervision power is insufficient . Although the audit strength of different enterprises exist distinction, pay attention to the supervision and management of key audit work, but compared with the overall audit scope, the coverage of audit supervision is not wide enough. The illegal means is forbidden hidden and diverse, if we want to carry out anti-corruption, we need to pay attention to the development of audit personnel, improve the efficiency and quality of audit work. However, the audit work of state-owned enterprises is complex, and the development speed of the talent team is slow, which can not meet the needs of enterprise audit work.

\section{Research Methods}

Audit efficiency measurement method: Using data envelopment analysis to measure audit efficiency represents the main direction of the research, Jeong-Bon et al. (2005), Lee (2009), etc., Lu Taiping and Zhang Dongxu (2014) analyzed the efficiency of accounting firms, Yu Caiping (2010), Li Lu and Xia Yu (2011) using data envelopment analysis to measure the efficiency of audit institutions. In order to fully reflect the efficiency of national audit, this paper starts from two levels of static and dynamic audit efficiency. In the aspect of static audit efficiency measurement, the common DEA efficiency measurement model includes CCR model and BCC model. Considering the CCR model of production possibility set with a convex cone to describe the lack of accuracy, this paper uses CCR model to remove the assumption of the cone BCC model, BCC model of variable returns to scale based on the assumption of strong objectivity and operability. Clculate the comprehensive efficiency value (CRSTE) of each decision unit by calculation、Pure technical efficiency value (VRSTE) and scale efficiency value (SCALE), SCALE=CRSTE/VRSTE. In the aspect of dynamic efficiency measurement,explore the deep factors that cause the change of audit efficiency through the Malmquist index, Malmquist index can be divided into technical efficiency change and technical progress efficiency change, namely $\mathrm{tfpch}=\mathrm{effch} \times \mathrm{techch}$, in which technical efficiency change can be decomposed into scale efficiency change and pure technical efficiency change, namelyeffch $=$ sech $\times$ pech.

\section{Analysis}

Efficiency analysis of regional audit. According to the division of administrative regions, the country is divided into seven regions, the average efficiency and the fitting slope region is shown in Table 1.

\begin{tabular}{|l|l|l|l|l|l|l|}
\hline \multirow{2}{*}{ Area } & \multicolumn{2}{|l|}{ Overall efficiency } & \multicolumn{2}{l|}{ Pure technical efficiency } & \multicolumn{2}{l|}{ Scale efficiency } \\
\cline { 2 - 7 } & $\begin{array}{l}\text { Average } \\
\text { value }\end{array}$ & Fitting slope & $\begin{array}{l}\text { Average } \\
\text { value }\end{array}$ & Fitting slope & $\begin{array}{l}\text { Average } \\
\text { value }\end{array}$ & Fitting slope \\
\hline $\begin{array}{l}\text { North } \\
\text { China }\end{array}$ & 0.67 & $0.0244 * * *$ & 0.87 & 0.0128 & 0.76 & $0.0181^{* * *}$ \\
\hline Northeast & 0.65 & $0.0149 * * *$ & 0.83 & $-0.0273 * * *$ & 0.78 & -0.020 \\
\hline East China & 0.83 & -0.0087 & 0.92 & $-0.0075^{* * *}$ & 0.90 & -0.0039 \\
\hline $\begin{array}{l}\text { Central } \\
\text { China }\end{array}$ & 0.85 & -0.0072 & 0.90 & $0.0084 * * *$ & 0.94 & -0.0144 \\
\hline $\begin{array}{l}\text { South } \\
\text { China }\end{array}$ & 0.82 & 0.0110 & 0.87 & 0.0021 & 0.94 & 0.0098 \\
\hline Southwest & 0.74 & $-0.0354 * * *$ & 0.88 & $-0.0240^{*}$ & 0.83 & -0.0194 \\
\hline Northwest & 0.74 & -0.0184 & 0.82 & -0.0025 & 0.90 & -0.0205 \\
\hline
\end{tabular}

Analysis of audit efficiency difference based on provinces aims to explore the key factors of regional audit efficiency differences, the analysis results are shown in Tabl2 2 


\begin{tabular}{|c|c|c|c|c|c|c|c|c|c|c|c|}
\hline $\begin{array}{c}\text { Provinc } \\
\mathrm{e}\end{array}$ & $\begin{array}{c}\text { Techn } \\
\text { ical } \\
\text { effici } \\
\text { ency }\end{array}$ & $\begin{array}{c}\text { Techn } \\
\text { ical } \\
\text { progr } \\
\text { ess } \\
\text { effici } \\
\text { ency }\end{array}$ & $\begin{array}{l}\text { Pure } \\
\text { techni } \\
\text { cal } \\
\text { effici } \\
\text { ency }\end{array}$ & $\begin{array}{l}\text { Scale } \\
\text { effici } \\
\text { ency }\end{array}$ & $\begin{array}{l}\text { Total } \\
\text { factor } \\
\text { produc } \\
\text { tivity }\end{array}$ & $\begin{array}{c}\text { Provin } \\
\text { ce }\end{array}$ & $\begin{array}{l}\text { Techn } \\
\text { ical } \\
\text { effici } \\
\text { ency }\end{array}$ & $\begin{array}{c}\text { Techn } \\
\text { ical } \\
\text { progr } \\
\text { ess } \\
\text { effici } \\
\text { ency }\end{array}$ & $\begin{array}{l}\text { Pure } \\
\text { techni } \\
\text { cal } \\
\text { effici } \\
\text { ency }\end{array}$ & $\begin{array}{c}\text { Scal } \\
\text { e } \\
\text { effic } \\
\text { ienc } \\
y\end{array}$ & $\begin{array}{l}\text { Total } \\
\text { factor } \\
\text { produ } \\
\text { ctivit } \\
\text { y }\end{array}$ \\
\hline Beijing & 1.02 & 1.00 & 1.01 & 1.02 & 1.02 & $\begin{array}{c}\text { Henan } \\
\mathrm{g}\end{array}$ & 0.97 & 0.89 & 0.97 & 1.00 & 0.87 \\
\hline Tianjin & 1.02 & 0.95 & 1.00 & 1.01 & 0.97 & Hubei & 1.04 & 0.90 & 1.03 & 1.00 & 0.97 \\
\hline Hebei & 1.01 & 0.91 & 1.00 & 1.01 & 0.92 & Hunan & 0.98 & 1.04 & 0.98 & 1.00 & 1.02 \\
\hline Shanxi & 1.06 & 0.88 & 1.01 & 1.05 & 0.93 & $\begin{array}{c}\text { Guang } \\
\text { dong }\end{array}$ & 0.87 & 1.03 & 0.90 & 0.97 & 0.90 \\
\hline $\begin{array}{l}\text { Inner } \\
\text { Mongol } \\
\text { ia }\end{array}$ & 1.16 & 0.95 & 1.09 & 1.07 & 1.10 & $\begin{array}{c}\text { Guang } \\
\text { xi }\end{array}$ & 0.86 & 0.98 & 0.98 & 0.88 & 0.84 \\
\hline $\begin{array}{c}\text { Liaonin } \\
\mathrm{g}\end{array}$ & 0.88 & 0.89 & 0.97 & 0.91 & 0.78 & Henan & 1.00 & 1.10 & 1.00 & 1.00 & 1.09 \\
\hline Jilin & 0.92 & 0.91 & 0.96 & 0.96 & 0.84 & $\begin{array}{c}\text { Sichua } \\
n\end{array}$ & 0.99 & 0.98 & 0.99 & 1.00 & 0.96 \\
\hline $\begin{array}{l}\text { Heilong } \\
\text { jiang }\end{array}$ & 0.92 & 0.87 & 0.92 & 1.00 & 0.80 & $\begin{array}{c}\text { Chong } \\
\text { qing }\end{array}$ & 1.01 & 0.81 & 1.01 & 1.00 & 0.82 \\
\hline $\begin{array}{c}\text { Shangh } \\
\text { ai }\end{array}$ & 1.00 & 1.19 & 1.00 & 1.00 & 1.19 & $\begin{array}{c}\text { Guizh } \\
\text { ou }\end{array}$ & 0.94 & 0.95 & 0.95 & 0.99 & 0.89 \\
\hline Jiangsu & 1.00 & 0.97 & 1.00 & 1.00 & 0.97 & $\begin{array}{c}\text { Yunna } \\
n\end{array}$ & 0.87 & 0.86 & 0.93 & 0.94 & 0.75 \\
\hline $\begin{array}{c}\text { Zhejian } \\
\text { g }\end{array}$ & 1.01 & 0.90 & 1.01 & 1.00 & 0.91 & Shanxi & 0.97 & 0.90 & 1.04 & 0.93 & 0.87 \\
\hline Jiangxi & 1.07 & 0.89 & 1.03 & 1.04 & 0.96 & Gansu & 1.03 & 0.86 & 1.04 & 0.99 & 0.89 \\
\hline Fujian & 0.95 & 0.93 & 0.97 & 0.98 & 0.89 & $\begin{array}{c}\text { Qingh } \\
\text { ai }\end{array}$ & 0.91 & 0.95 & 1.02 & 0.90 & 0.87 \\
\hline Anhui & 1.01 & 0.80 & 1.07 & 0.94 & 0.81 & $\begin{array}{c}\text { Ningxi } \\
\text { a }\end{array}$ & 0.89 & 0.87 & 1.00 & 0.89 & 0.78 \\
\hline $\begin{array}{c}\text { Shando } \\
\text { ng }\end{array}$ & 1.00 & 0.99 & 1.00 & 1.00 & 0.99 & $\begin{array}{c}\text { Xinjia } \\
\text { ng }\end{array}$ & 0.95 & 0.94 & 0.97 & 0.98 & 0.89 \\
\hline
\end{tabular}

\section{Conclusions and Countermeasures}

This paper uses DEA model of BCC to measure the static audit efficiency of state-owned enterprises, and then explores the main factors that cause the change of audit efficiency through the Malmquist index: (1)The comprehensive efficiency audit of state-owned enterprises in China, pure technical efficiency and scale efficiency did not reach the standard of efficiency, the overall audit efficiency is not ideal.(2)The results of regional static provincial efficiency analysis show that the average efficiency of regional audit efficiency shows obvious regional characteristics, the degree of difference is significant, and the level of regional economic development influences the realization of the function of national audit immune system(3)The dynamic change trend of provincial audit efficiency analysis results show that the state-owned enterprise audit efficiency decreased, the scale efficiency is the main reason for decline of efficiency reduction, the provincial audit efficiency balance is the key to eliminate regional differences.

According to the above analysis, under the overall deepening reform, the audit work of state-owned enterprises is faced with many challenges and difficulties, which hinder the smooth development of the enterprise economic system reform, optimize the audit countermeasure analysis mainly from the talent team construction, audit supervision work and audit mode.

The implementation of audit work in state-owned enterprises is inseparable from the talents, and strengthening the construction of talent team is a development project that must be paid attention to in the overall deepening reform of the economic system. First of all, state-owned enterprises need to 
strengthen the supplement and training of audit professionals. There are many professional fields of enterprise audit design, such as computer major, economic management specialty and financial accounting specialty, etc., enterprises should pay attention to the supplementary work of professional talents, and build a comprehensive audit personnel team. For the backbone staff of the enterprise audit institutions, we can send them to the enterprise supervision departments for exchange of experience and practice, in order to improve the audit staff's supervision and management ability. For professional training of enterprise audit staff, we should pay attention to the work quality, work function and professional knowledge of Auditors. At the same time, organize auditors' experience exchange and work discussion meetings to promote the internal communication of auditors and motivate the efficiency of Auditors. The state-owned enterprises should focus on the long-term development, pay attention to the construction of audit resource database, and strengthen the cooperation between enterprises and social audit departments, universities and research institutions and other organizations, and jointly establish audit data files. In addition, audit experts with rich experience and practical ability to audit data, combined with the progress of enterprise audit work, audit data files updated. Enterprises can hire experts in economic management with high salary, audit theoretical discussions and special training for auditors, improve auditors' horizons and broaden their thinking ability. The state-owned enterprises should carry out the construction of audit talent team in many aspects, and constantly improve the work level and quality of the auditors.

\section{Conclusion}

Comprehensive analysis above, under the comprehensive deepening of reform, the audit of state-owned enterprises may exist deficiencies and loopholes, enterprises should promptly do a good job of complement and improve. Audit quality of state owned enterprises is related to national economic development and people's interests, the state-owned enterprises must pay attention to the audit model, auditors and audit supervision optimization, improve the quality of audit work.

\section{Acknowledgment}

Longdong University doctoral research start-up funding project (No.: XYBE1605).

\section{References}

[1] He Guocheng. Several issues on the audit of state owned enterprises under the background of deepening reform $[\mathrm{J}]$. Audit research.2014(06)

[2] Xing Li, Qiu Wenhong, Zhang Peiyao, and. Discussion on service innovation of cultural and Creative Park: cultural value perspective [J]. macroeconomic management, 2017, (S1): 34-36.

[3] Liang Xiaoli, Wang Liang. Research on budget audit of state owned capital management under the background of reform [J]. Shanghai state - owned assets.2014(09) .

[4] Li, X,Lin, M, Analysis of Efficiency of Exploration Type Outgoing Economic Responsibility Audit Internal Audit Factors (CFA) Study,PROCEEDINGS OF THE 2015 INTERNATIONAL CONFERENCE ON INDUSTRIAL TECHNOLOGY AND MANAGEMENT SCIENCE (ITMS 2015),ACSR-Advances in Comptuer Science Research,International Conference on Industrial Technology and Management Science,MAR 27-28, 2015,pp1852-1855,WOS:000373400200452 